\title{
Improving Students' English Speaking Skill Through the Implementation of Talking Stick Method to the Fifth Grade Students of State Primary School 028226 Binjai
}

\author{
${ }^{1}$ Anna Stasya Prima Sari, ${ }^{2}$ Ribka Kariani Br Sembiring \\ ${ }^{1,2}$ Universitas Katolik Santo Thomas, Indonesia \\ 1annastasya3105@gmail.com²ribkakariani@gmail.com
}

\begin{abstract}
This research was primarily carried out to prove that the implementation of Talking Stick method could improve students' English speaking skill and to describe the students' responses to the implementation of Talking Stick method in the learning teaching processes of English speaking skill. This research is Classroom Action Research (henceforth, CAR) which was carried out in two cycles. Each cycle consisted of four meetings. The research subject of this CAR are the fifth grade students of State Primary School 028226 Binjai Class V-1 in the Academic Year of 2019/2020. There are 33 students as the research subject. The analysis of quantitative data showed that the students' mean score increased continually from 55,63 in the pretest, 66,36 in the posttest of cycle 1, to 76,81 in the posttest of cycle 2. The analysis of qualitative data showed that the learning teaching processes of English speaking skill through the implementation of Talking Stick method ran very well. The students were more active, and motivated to learn English speaking skill. The class atmosphere was more alive and enjoyable after Talking Stick method was implemented in the English speaking classes. It is advisable that English teachers of primary school students apply Talking Stick method as one of alternatives to improve their students' English speaking skill.
\end{abstract}

Keywords: English speaking skill; talking stick method, classroom action research

\section{Introduction}

There are four language skills which need to be achieved in order to complete communication. They are listening, speaking, reading, and writing. Actually all of the English skills are important, but speaking skill is the most important skill that should be mastered by English learners since the goal of learning a language is speaking. In the international relationship, English speaking skill is required by people in the wider world of work. This reality makes teachers and parents think that English speaking skill should be mastered by their students and children.

In Indonesia, English language has been long taught formally from kindergarten level up to university level. But it is no wonder that most Indonesian students cannot speak English language fluently. In general, some people realize that there are some factors which make the students difficult to speak English language. They are internal and external factors. The internal factor comes from the students themselves. It is about their motivation to learn and practise. External factors come from out of the students. The external factors concern with the teaching approach/method/technique and the environment itself. The teacher's approach/method/technique in teaching English speaking skill should be so attractive to the students that they will actively participate in the classroom activities. Environment also plays a crucial role in learning English language.

Based on the writers' observation to the fifth grade students of State Primary School 028226 Binjai Class V-1 in the Academic Year of 2019/2020, the writers found some problems in the learning teaching process of speaking skill. Firstly, the English teacher hardly gives the students various activities, such as games, students' project, delivering speech, presentation and discussing some issues outside classroom activities. The class is monotonous and less fun. 
In addition, the students do not try to find out the materials by themselves to suffice or to accommodate their own needs in learning English. Secondly, the students' speaking skill is relatively low. They have difficulties in expressing their ideas and opinions orally as they are afraid of making mistakes, and lack of confidence to speak English. They still have difficulties in pronouncing certain English words, for examples: introduce, myself, people, call, study, etc. To be able to speak, a large amount of vocabulary is also important, because without adequate vocabulary there is nothing to say. However, most students lack of vocabulary mastery and only few students in the classroom consult a dictionary. Their competencies in grammar are also poor. Therefore, they prefer to be silent and not fully participate in the classroom activities.

Teaching English for young learners is different from teaching English for adults. A teacher should be aware that the learners are children and they are different from adults. Teaching English for young learners needs to consider children's emotional, cognitive and physical development (Linse, 2005:3). Considering the English speaking problems faced by the fifth grade students of State Primary School 028226 Binjai Class V-1 in the Academic Year of 2019/2020, the writers aroused to implement Talking Stick method to improve their English speaking skill.

This research needs to be carried out because if it is not conducted the writers will not be able to know the students' real problems in English speaking skill and will not be able to give any treatment in order to improve their English speaking skill. Meanwhile if this research is carried out, it will give some positive significance to the writers and the English teacher so that they know how far the students have improvement in their English speaking skill. Through this research, the students will get a new experience to improve their English speaking skill through the implementation of Talking Stick method.

Teaching English for young learners is not an easy task. There are so many aspects which need to be considered. The main objectives of this research is to prove that the application of Talking Stick method could improve the students' English speaking skill and to describe the students' responses to the implementation of Talking Stick method in the learning teaching processes of English speaking skill. The writers strongly believe that the implementation of an approprite teaching method can improve students' motivation and interest in learning English speaking skill. If the students' motivation and interest in learning English speaking skill improve, their English speaking skill will definitely improve. The strong belief made the writers interested in conducting a research entitled Improving Students' English Speaking Skill through the Implementation of Talking Stick Method to the Fifth Grade Students of State Primary School 028226 Binjai.

\section{Review of Literature}

\subsection{Speaking Skill}

Speaking is a language skill that has to be mastered by students in learning a language because the objective of learning a language is communication. Richards (2008:19) states that in speaking we tend to be getting something done, exploring ideas, working out some aspects of the world, or simply being together. Speaking English well also helps students access up to update information in fields including science, technology and health. The students have to master all components of speaking skill. According to Fulcher \& Davidson (2006: 94), there are five components of speaking skill that can be defined as follows: 
1. Pronunciation: Pronunciation is the way for students to produce clearer language when they are speaking. It means that the student can communicate effectively when they have good pronunciation and intonation even though they have limited vocabulary and grammar. Pronunciation refers to the traditional or customary utterance of words.

2. Grammar: Grammar is needed for the students to arrange correct sentences in conversation both in written and oral forms. Grammar is defined as a systematic way of accounting for and predicting an ideal speaker's or hearer's knowledge of the language. This is done by a set of rules or principles that can be used to generate all well-formed or grammatical utterances in the language. Thus from statement above can be concluded that grammar is a rule that is needed for the students to combine correct sentences in conversation both in written and oral forms.

3. Vocabulary: Vocabulary is essential for successful second language use. Without an extensive vocabulary, we will be unable to use the structure and function we may have learnt for comprehending the communication. It can be said that one key the success in communicative, which is the power of words. It means that in spoken language or speaking, the vocabulary used must be very familiar and it is used in everyday conversation in order to understand the spoken. Vocabulary is the knowledge of meanings of words. What complicates this definition is the fact that words come in at least two forms: oral and written. Oral vocabulary is the set of words for which we know the meanings when we speak or read orally. Written vocabulary consists of those words for which the meaning is known when the writing activities. These are important distinctions because the set of words that beginning readers know are mainly oral representations. As they learn to read, written vocabulary comes to play an increasingly larger role in literacy than does the oral vocabulary.

4. Fluency: Fluency is defined as the ability to speak communicatively, fluently and accurately. Fluency usually refers to express oral language freely without interruption. In teaching and learning process, if the teacher wants to check students' fluency, the teacher allows students to express themselves freely without interruption. The aim is to help students speak fluently and with ease. The teacher does not correct immediately whereas the idea being that too much correction interferes with the flow of conversation.

5. Comprehension: Comprehension is an ability to perceive and process stretches of discourse, to formulate representations the meaning of sentences. Comprehension of a second language is more difficult to study since it is not directly observable and must

6. be inferred from verbal and nonverbal responses by artificial instruments or by the intuition of the teacher or researcher. In brief, comprehension refers to the speakers' understanding about what they are saying to the listeners in order to avoid misunderstanding information.

In order to measure the students' English speaking skill mastery, the first writer and the collaborator (Mrs. Widya) used speaking rubric proposed by O'Malley and Pierce (1990) as follow: 
Budapest International Research and Critics in Linguistics and Education (BirLE) Journal Volume 2, No 4, November 2019, Page: 507-513 e-ISSN: 2655-1470 (Online), p-ISSN: 2655-2647(Print) www.bircu-journal.com/index.php/birle emails:birle.journal@gmail.com birle.journal.qa@gmail.com

Table 2.1 Speaking Rubric Proposed by O’Malley and Pierce (1990)

\begin{tabular}{|c|c|c|c|}
\hline Aspects & Score & Criteria & Indicator \\
\hline \multirow{4}{*}{$\begin{array}{l}\text { Pronuncia- } \\
\text { tion and } \\
\text { Intonation }\end{array}$} & 1 & Poor & $\begin{array}{l}\text { Makes frequent problems with pronunciation and } \\
\text { intonation }\end{array}$ \\
\hline & 2 & Fair & $\begin{array}{l}\text { Pronunciation and intonation are sometimes not clear } \\
\text { or accurate }\end{array}$ \\
\hline & 3 & Good & Pronunciation and intonation are clear or accurate \\
\hline & 4 & Excellent & $\begin{array}{l}\text { Pronunciation and intonation are almost always clear } \\
\text { or accurate }\end{array}$ \\
\hline \multirow[t]{4}{*}{ Fluency } & 1 & Poor & $\begin{array}{l}\text { Hesitates too often when speaking, which interferes } \\
\text { the communication }\end{array}$ \\
\hline & 2 & Fair & $\begin{array}{l}\text { Speaks with some hesitation, which often interferes } \\
\text { the communication }\end{array}$ \\
\hline & 3 & Good & $\begin{array}{l}\text { Speaks with some hesitation, which seldom interferes } \\
\text { the communication }\end{array}$ \\
\hline & 4 & Excellent & $\begin{array}{l}\text { Speaks smoothly, with little hesitation that does not } \\
\text { interfere the communication }\end{array}$ \\
\hline \multirow[t]{4}{*}{ Accuracy } & 1 & Poor & Uses basis structures and makes frequent errors \\
\hline & 2 & Fair & $\begin{array}{l}\text { Uses a variety of structures with frequent errors, or } \\
\text { uses basic structures occasionally }\end{array}$ \\
\hline & 3 & Good & $\begin{array}{l}\text { Uses a variety of grammatical structures, but makes } \\
\text { some errors }\end{array}$ \\
\hline & 4 & Excellent & $\begin{array}{l}\text { Uses a variety of structures with only occasional } \\
\text { grammatical errors }\end{array}$ \\
\hline \multirow[t]{4}{*}{ Vocabulary } & 1 & Poor & Uses only basic vocabulary and expressions \\
\hline & 2 & Fair & Uses limited vocabulary and expressions \\
\hline & 3 & Good & $\begin{array}{l}\text { Uses a variety of vocabulary and expressions, but } \\
\text { makes some errors in the word choice }\end{array}$ \\
\hline & 4 & Excellent & $\begin{array}{l}\text { Uses a variety of vocabulary and expressions and } \\
\text { almost never makes some errors in the word choice }\end{array}$ \\
\hline
\end{tabular}

\subsection{Talking Stick Method}

According to Kagan (2009:82), Talking stick method is a method in the learning process by a stick. The student who gets the stick must answer the questions by the teacher after studying the materials. follows:

According to Kagan (2009:84), the procedures of applying Talking Stick method are as

1) The teacher prepares a stick.

2) The teacher explains the learning material. Then, the teacher asks the students to make up a conversation based on the learning material

3) The teacher gives the stick to the students.

4) The teacher sings a song or plays music while the stick moves from one student to another one until the song or music stops.

5) The student who gets the stick must perform the conversation in front of the class with his friend.

6) Further, the stick rolls on again until each student gets the stick and takes part in the learning process of speaking skill.

7) Finally, the teacher gives the evaluation and makes conclusion. 


\section{Research Method}

\subsection{Research Design}

This research is Classroom Action Research (henceforth, CAR). According to Burns (2010: 2), action research is related to the ideas of "reflective practice" and "the teacher as researcher" involves taking a self-reflective, critical, and systematic approach to exploring your own teaching context. In other words, action research is defined to solve the problems through direct application in the classroom and improving outcomes of teaching and learning. Furthermore, McKay (2006:29) says that action research has three major characteristics: it is carried out by practitioners (i.e., classroom teachers), it is collaborative, and it is aimed at changing things. It means that action research can be done by a teacher in a classroom with the help of other teachers to discuss what and how to improve the classroom activities so that the students' learning achievement will be better.

Based on the definitions above, it is concluded that CAR is a form of research in which an idea in a social or educational situation is alpplied in order to improve or change something to be better, or to get real effect on the situations. In carrying out this CAR, the first writer collaborated with the English teacher of the fifth grade students of State Primary School 028226 Binjai Class V-1 in the Academic Year of 2019/2020, that is Mrs. Wi dya to help her define and explore certain problems and needs in the classroom.

The writers used CAR model developed by Kemmis \& McTaggart (1998). This CAR was arranged into two cycles, namely cycle one and cycle two. Kemmis \& McTaggart (1998) state that action research typically involves four broad phases in a cycle of research. The four phases in a cycle are: (1) planning, (2) action, (3) observation, and (4) reflection. The four phases can be seen in the figure 3.1.

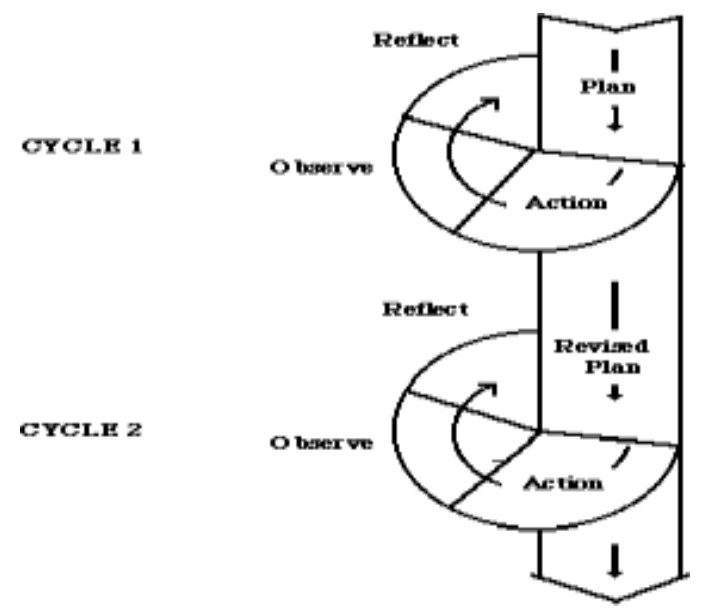

Figure 3.1 The Classroom Action Research (CAR) Model Developed by Kemmis and McTaggart (1998)

The four steps in cycle 1 and cycle 2 are explained as follows:

1. Planning

Planning is the first step of the CAR procedure. This activity covers the problem identification. This is the most important step in conducting CAR since by knowing the problems, the writers could find an excellent solution to solve the problems. 


\section{2) Action}

In this step, the scenario of learning teaching processes of English speaking skill through the implementation of Talking Stick method was implemented in the classroom activities.

\section{3) Observation}

Observation was done when the action was being done. In this step, the students' participation and behaviour and the first writer's action during the learning teaching processes of English speaking skill through the implementation of Talking Stick method were observed by Mrs. Widya who acted as a collaborator in this research. Observation was done in order to get the actual data and to be used as a reflection to improve the quality of learning teaching processes of English speaking skill through the implementation of Talking Stick method.

\section{Reflection}

The data which were obtained such as the students' English speaking scores in the pretest, posttest of cycle 1 and posttest of cycle 2, the extent of students' participation and behaviour, and the first writer's action during the learning teaching processes of English speaking skill through the implementation of Talking Stick method were collected and analyzed. In brief, the quantitative and qualitative data were analyzed to assess the students' progress or achievement in learning English speaking skill through the implementation of Talking Stick method.

\subsection{Research Subject}

Research subject of this CAR are the fifth grade students of State Primary School 028226 Binjai Class V-1 in the Academic Year of 2019/2020. The numbers of students in that class are 33 students, consisting of 23 female students and 10 male students.

There are two reasons why the writers chose State Primary School 028226 Binjai as the location of the research. They are: 1) Based on the preliminary observation done by the first writer, it was found that the students' English speaking skill needs to be improved, and 2) Based on the writers' knowledge, there has never been any research about improving students' English speaking skill through the implementation of Talking Stick method.

\section{Data Analysis and Research Findings}

After analyzing the quantitative and qualitative data, it was found that the implementation of Talking Stick method could improve the students' English speaking skill . It could be seen from the increasing of the students' mean score from the pretest to the posttest of cycle 2 . The students' mean score in the pretest is 55,63, in the posttest of cycle 1 is 66,36 , and in the posttest of cycle 2 is 76,81. From the result, it was concluded that the implementation of Talking Stick method had successfully improved the students' English speaking skill.

The students' responses to the learning teaching processes of English speaking skill through the implementation of Talking Stick method are very positive. All of them agreed that the implementation of Talking Stick method could improve their English speaking skill. The analysis of qualitative data showed that the students were more active and enthusiastic in speaking the English language after Talking Stick method was implemented in the speaking classes. 


\section{Conclusions and Suggestions}

To wrap up, the writers conclude that:

1) The implementation of Talking Stick method could improve the students' English speaking skill. It could be seen from the increasing of the students' mean score from the pretest to the posttest of cycle 2 . The students' mean score in the pretest is 55,63, in the posttest of cycle 1 is 66,36 , and in the posttest of cycle 2 is 76,81 .

2) The students' responses after learning English speaking skill through the implementation of Talking Stick method are very positive. All of them agreed that the implementation of Talking Stick method could improve their English speaking skill. The analysis of qualitative data showed that the learning teaching atmosphere became more alive and enjoyable after Talking Stick method was implemented in the speaking classes so that the students were more active and enthusiastic in speaking the English language.

In line with the conclusions, it is advisable that:

1) English teachers for primary school students had better teach English speaking skill by implementing Talking Stick method because the implementation of Talking Stick method is able to create a pleasant and challenging learning atmosphere so that students feel more motivated and interested in learning English speaking skill,

2) The learners of English are suggested to practice speaking in the English language more and more. The more they practice speaking in the English language, the better their English speaking skill will be. They should be active and enthusiastic in the speaking classes and need not to be shy or afraid of making mistakes,

3) Other writers who are going to conduct much deeper studies on improving students' English speaking skill through the implementation of Talking Stick method; the results of this research are expected to be able to provide them valuable information about how to improve students' English speaking skill through the implementation of Talking Stick method.

\section{References}

Burns, A. 2010. Doing Action Research in English Language Teaching: A Guide for Practitioners. New York: Routledge.

Fulcher, G., \& Davidson, F. 2006. Language Testing and Assessment: An Advanced Resource Book. New York: Routledge.

Kagan, S. 2009. Cooperative Learning. San Clamente: Kagan Publishing.

Kemmis., \& McTaggart, R. 1997. Participatory Action Research: International Context and Consequences. New York: State University of New York.

Linse, C.T. 2005. Practical English Language Teaching for Young Learners. North Carolina: McGraw-Hill Companies.

McKay, S. L. 2006. Researching Second Language Classrooms. London: Lawrence Erlbaum Associates.

O’Malley, J. M., \& Pierce, L. V. 1990. Authentic Assessment for English Language Learner: Practical Approach for Teacher. Massachusetts: Addison Wesley.

Richards, J. 2008. Teaching Listening and Speaking from Theory to Practice. Cambridge: Cambridge University Press. 